\title{
Ligand-Free Palladium-Catalyzed Cyanation of Aryl Halides
}

\section{Steven A. Weissman, 'Daniel Zewge, Cheng Chen}

General Considerations: All reactions were carried out in a nitrogen atmosphere. All starting materials (with the exception of $\mathbf{1}$ ), reagents and solvents were obtained from commerical sources and were used without purification. Assay yields were determined using HPLC in comparison to reference standards. All known compounds (entries 2-12) were identified by NMR $\left({ }^{1} \mathrm{H},{ }^{13} \mathrm{C}\right)$ and were identical to published values (Aldrich Library of NMR Spectra; $2^{\text {nd }}$ Edition, 1983) .

Compound 2:Sample was purified via recrystallization from toluene/heptane. ${ }^{1} \mathrm{H}$ NMR $(400.13 \mathrm{MHz}$, $\left.\mathrm{CDCl}_{3}\right): \delta 7.57(\mathrm{td}, J=7.2,1.6 \mathrm{~Hz}, 1 \mathrm{H}), 7.48(\mathrm{~m}, 1 \mathrm{H}), 7.44(\mathrm{t}, J=7.2 \mathrm{~Hz}, 1 \mathrm{H}), 7.41(\mathrm{td}, J=7.2,1.6 \mathrm{~Hz}$, $1 \mathrm{H}), 7.19(\mathrm{~m}, 2 \mathrm{H}), 6.95(\mathrm{~m}, 2 \mathrm{H}), 3.93(\mathrm{t}, J=7.6 \mathrm{~Hz}), 3.38(\mathrm{dd}, J=14.0,7.5 \mathrm{~Hz}, 1 \mathrm{H}), 2.87(\mathrm{dd}, J=14.0$, $7.5 \mathrm{~Hz}, 1 \mathrm{H}), 2.06(\mathrm{~s}, 3 \mathrm{H}) .{ }^{13} \mathrm{C}$ NMR $(100.61 \mathrm{MHz}): 206.1,139.4,136.9,132.6,132.3,132.1,131.7$, 131.2, 130.2, 129.7, 128.5, 118.2, 113.1, 60.5, 37.8, 29.8. Anal. Calcd. For $\mathrm{C}_{17} \mathrm{H}_{14} \mathrm{ClNO}$ : C, 71.96; $\mathrm{H}$, 4.97; N, 4.94. Found: C, 71.86; H, 4.99; N, 4.85. mp: 71-72 ${ }^{\circ} \mathrm{C}$.

Actual $\mathrm{Pd}(\mathrm{OAc})_{2}$ Charges from Table 1: (Unoptimized in the 0.1-0.5 mole \% range):

\begin{tabular}{|c|c|}
\hline Entry & Mole\% Pd(OAc $)_{2}$ \\
\hline 1 & 0.5 \\
\hline 2 & 0.15 \\
\hline 3 & 0.1 \\
\hline 4 & 0.15 \\
\hline 5 & 0.5 \\
\hline 6 & 0.15 \\
\hline 7 & 0.3 \\
\hline 8 & 0.1 \\
\hline 9 & 0.1 \\
\hline 10 & 0.5 \\
\hline 11 & 0.2 \\
\hline 12 & 0.1 \\
\hline
\end{tabular}

